\title{
Transportation Fuel Taxes in Poland as Climate Policy Instruments
}

\author{
Michał PTAK \\ Wrocław University of Economics, Wrocław, Poland \\ Michal.Ptak@ue.wroc.pl
}

\begin{abstract}
The aim of the article is to analyse taxes and charges levied on motor fuels in Poland by reviewing their design from the perspective of climate policy and carbon dioxide emissions reduction. The analysis includes levies that fall under the scope of the of 2003/96/EC Directive on energy taxation: an excise duty and a fuel charge levied on gasoline, diesel oil, liquefied petroleum gas and compressed natural gas. The value added, tax has been excluded from the analysis. The paper concludes that fuel taxes in Poland have not been designed for climate policy and are mostly revenue-generating taxes. Tax rules that contribute to carbon dioxide emissions reduction include lower tax rates for gaseous fuels and the use of fuel charge revenues to finance investments in railway infrastructure. Excise duty in Poland could be redesigned to better reflect climate policy objectives. The tax could be for example combined with a direct carbon tax based on carbon dioxide emissions. Such taxes are applied in some European countries, for example in Finland or Sweden.
\end{abstract}

Keywords: Climate Policy, Motor Fuels, Taxes

\section{Introduction}

Road transport is a significant source of carbon dioxide $\left(\mathrm{CO}_{2}\right)$ emissions, which result from fuel combustion in vehicle engines. Two of the most popular transport fuel types include gasoline and diesel oil. Some of the vehicles are fueled with gaseous fuels such as liquefied petroleum gas (LPG) or compressed natural gas (CNG). In general, burning fossil carbon-based fuels contributes not only to climate change, but also causes plenty of other environmental damage such as air pollution or noise.

One of the main instruments to provide incentives to change the behavior of vehicle users in order to reduce fuel consumption, greenhouse gas emissions and other external effects of road transport has been taxes levied on fuels. Taxes are incorporated into the price of the fuels and can be differentiated in order to enhance drivers to buy fuels with a low environmental impact.

The aim of the paper is to analyse taxes levied on transportation fuels in Poland by reviewing their design from the perspective of climate policy and carbon dioxide emissions reduction. The author also compares motor fuel taxes used in Poland to 
taxes applied in the European Union countries. The value added, tax has been excluded from the analysis.

\section{Fuel taxes as climate policy instruments}

Fuel taxes are often in the form of typical excise duties. In general, excise duties are indirect taxes included in the price of certain consumer goods. Excise duties are mostly levied by central governments and are primarily directed towards raising revenues. However, experience of some countries suggests that excise duties (strictly tax differentiations) have contributed to correct some negative externalities of road transport. In the past, differences in tax rates accelerated the withdrawal of leaded gasoline and high sulphur diesel from the market [4].

Although many excise duties on fuels may not have been originally put in place for climate protection purposes they surely provide incentives to change the behavior of vehicle users in order to reduce greenhouse gas emissions [14]. The fifth IPCC report, released in 2014, includes fuel taxes in the group of policy instruments that have been implemented in practice to mitigate climate change. Other taxes on transport-related emission sources include vehicle taxes on the purchase or ownership of cars, road tolls and congestion charges for the use of the roads or for entering city centers by cars [14].

The OECD, the European Commission and Eurostat consider taxes levied on fuels as environmental taxes. Definition adopted by these institutions states that "an environmental tax is a tax whose base is a physical unit (or a proxy of a physical unit) of something that has a proven, specific negative impact on the environment [10]". The tax base can be specified as a given amount of polluting emissions or as a proxy for emissions, which are difficult to measure. The use of motor fuels can be used as such a proxy [10]. The list of environmental tax bases established to identify environmental taxes includes inter alia "energy products for transport purposes", such as petrol, diesel, LPG and natural gas [10]. Eurostat also defines transport fuel taxes, which are considered "taxes on energy products used for transport purposes only [11]".

It should be noted that value added taxes are excluded from the scope of the OECD/Eurostat definition of environmental taxes. This is due the fact that VAT is levied on nearly all goods, is deductible for some producers (but not for individuals) and affects relative prices in other ways than environmental taxes [10].

Fuel taxes reduce greenhouse gas emissions by reducing travel demand (car use) and fuel use per kilometer, by encouraging consumers to buy more fuel-efficient vehicles and by making fuels with less carbon content more economically viable [37]. Taxes levied on fuels and differentiation in tax rates can also contribute to a reduction of other environmental impact of transport, such as noise and air pollution from nitrous oxides or particulates emissions.

Fuel taxes seem to be straightforward policy instrument to cut greenhouse gas emissions from the transport sector as there is a direct link between the use of carbonbased fuels and $\mathrm{CO}_{2}$ emissions [29]. In theory, tax rates should reflect the social cost 
of carbon from fuel use that is marginal damage generated by an additional tonne of carbon dioxide. The mean of published estimates of social cost of carbon is 53.5 dollars per tonne of $\mathrm{CO}_{2}$, and the median is 36.8 dollars per tonne of $\mathrm{CO}_{2}$ [33].

The effectiveness or ineffectiveness of excise duties as climate policy instruments depends on demand price elasticity of transport fuels [3]. Studies show that short-term elasticity of demand for motor fuels is low. This can be due that significant shift to alternative fuels is difficult [12]. In such a situation, the excise duties are pure revenue-generating taxes [1]. In the longer term, the price elasticities are higher and the taxes encourage motorists to reduce fuel use [32]. According to one meta-analysis short-term price elasticity of gasoline is -0.36 and a long-term elasticity is -0.81 [2].

Rates of environmentally related taxes should be adjusted for inflation to preserve incentive effect of the taxes. Furthermore, fuel tax rates should be gradually increased over time in order to reflect the rising marginal damage associated with rising $\mathrm{CO}_{2}$ concentration in the Earth's atmosphere [13]. It should be noted that the extent of the damages caused by climate change does not depend on current emissions of warming gases, but on the atmospheric concentration of these gases, which is the result of past years' emissions [28]. In the period 1970-2014 the concentration of greenhouse gases increased by $37 \%$. At the same time $\mathrm{CO}_{2}$ concentration increased by $22 \%$ up to 397 ppm [9]. Most of the carbon dioxide emissions come from fuel combustion.

The structure of excise duties is harmonized across the European Union to a limited degree. The Directive 2008/118/EC concerning the general arrangements for excise duty defines excise duty as a tax levied directly or indirectly on the consumption of certain goods [7]. Excise goods include inter alia energy products (motor and heating fuels) covered by Directive 2003/96/EC [6]. A so-called Energy Directive establishes the minimum levels of taxation that Member States must apply to energy products and allows the Member States to grant specific tax exemptions or reductions. Level of taxation is the total charge levied in respect of excise duties and all other indirect taxes (excluding VAT) calculated directly or indirectly on the quantity of fuels at the time of release for consumption. The minimum level of taxation for gasoline and diesel is 359 and 330 euro per 10001 respectively, for LPG 125 euro per $1000 \mathrm{~kg}$, and for $\mathrm{CNG}-2.6$ euro per GJ.

The establishment of minimum levels of taxation had to ensure the proper functioning of the internal market of the European Union but some environmental and climate concerns were also considered. One can assume that minimum tax rates also help to eliminate "tank tourism" when drivers are driving to neighboring countries to buy fuel with lower tax rates [20].

\section{$3 \quad$ Fuel taxes in Poland}

The fuel taxes in Poland comprise two kinds of levies: an excise duty and a fuel charge. Both kinds of levies fall under the scope of the Energy Directive.

Excise duty is governed by the 2008 Excise Duty Law, which entered into force on 1 March 2009 [36]. The tax is levied on motor and heating fuels, electricity, passenger cars, lubricating oils, alcohol and tobacco. The excise duty on transportation fuels is 
paid by those who produce or process fuels (eg. refineries). Taxpayers pass the tax burden onto the consumers by including it in the fuels' price. The excise tax revenues are allocated to the general government budget. Revenues generated from excise duty on fuels account for about one tenth of the total budget tax revenue [19].

The introduction of fuels for propellant applications to the Polish market is also subject to the fuel charge, which is generally treated in the literature as a type of tax [23]. The charge revenues are extra-budgetary resources and are earmarked for the National Road Fund and the Railway Fund. The funds' resources are allocated to investments in road and railway infrastructure. The rates of the fuel charge are adjusted annually for inflation. This is not the case for excise duty. The 2008 Law on Excise Duty does not introduce any mechanism for adjusting tax rates with inflation.

Excise duty and fuel charge on fuels are originally levied according to volume (in the case of gasoline and diesel), weight or carbon content (in the case of LPG and $\mathrm{CNG}$ ). The share of indirect taxes (excluding VAT) in average gasoline prices increased from $29 \%$ in 2012 to $38 \%$ in 2016 . At the same time the share of taxes in average diesel prices grew from $25 \%$ to $35 \%$. The rates of taxes are shown in Table 1 .

Table 1. Excise duty and fuel tax rates on transportation fuels in Poland. [8, 36]

\begin{tabular}{|c|c|c|c|c|c|c|c|c|c|}
\hline Specification & 2009 & 2010 & 2011 & 2012 & 2013 & 2014 & 2015 & 2016 & 2017 \\
\hline \multicolumn{10}{|c|}{ Gasoline (1000 1) } \\
\hline Excise (PLN) & 1565 & 1565 & 1565 & 1565 & 1565 & 1565 & 1540 & 1540 & 1540 \\
\hline Fuel charge (PLN) & 87 & 93 & 95 & 99 & 103 & 104 & 129 & 129 & 129 \\
\hline Indirect taxes (PLN) & 1651 & 1658 & 1660 & 1664 & 1668 & 1669 & 1669 & 1669 & 1669 \\
\hline Indirect taxes (euro) & 488 & 391 & 422 & 380 & 406 & 395 & 399 & 393 & 389 \\
\hline \multicolumn{10}{|c|}{ Diesel oil (1000 1) } \\
\hline Excise (PLN) & 1048 & 1048 & 1048 & 1196 & 1196 & 1196 & 1171 & 1171 & 1171 \\
\hline Fuel charge (PLN) & 98 & 234 & 240 & 250 & 260 & 263 & 288 & 288 & 288 \\
\hline Indirect taxes (PLN) & 1146 & 1282 & 1288 & 1446 & 1456 & 1459 & 1459 & 1459 & 1459 \\
\hline Indirect taxes (euro) & 339 & 302 & 327 & 330 & 355 & 345 & 349 & 344 & 340 \\
\hline \multicolumn{10}{|c|}{ LPG $(1000 \mathrm{~kg})$} \\
\hline Excise (PLN) & 695 & 695 & 695 & 695 & 695 & 695 & 670 & 670 & 670 \\
\hline Fuel charge (PLN) & 116 & 120 & 123 & 128 & 133 & 134 & 160 & 160 & 160 \\
\hline Indirect taxes (PLN) & 811 & 815 & 818 & 823 & 828 & 829 & 830 & 830 & 830 \\
\hline Indirect taxes (euro) & 240 & 192 & 208 & 188 & 202 & 196 & 198 & 195 & 193 \\
\hline \multicolumn{10}{|c|}{ CNG (1 GJ) } \\
\hline Excise (PLN) & & & & & 11.0 & 10.5 & 10.5 & 10.5 & 11.0 \\
\hline Fuel charge (PLN) & & & & & 3.1 & 3.7 & 3.7 & 3.7 & 3.1 \\
\hline Indirect taxes (PLN) & & & & & 14.2 & 14.3 & 14.3 & 14.3 & 14.2 \\
\hline Indirect taxes (euro) & & & & & 3.4 & 3.4 & 3.4 & 3.3 & 3.4 \\
\hline
\end{tabular}


Table 1 shows that the excise duty rate on gasoline remained constant during 20092014. As of 1 January 2015, the rate on gasoline and tax rates applicable to diesel oil, biofuels and gaseous transportation fuels were slightly reduced [35]. The reduction of excise duty rates, were offset by increases in fuel charge rates, which were introduced in order to maintain fuel prices and to raise funds for railway infrastructure projects. It can be assumed that such a shift in energy taxation will contribute towards improving the competitiveness of railway transport [26]. The reduced excise duty rates apply until 2019.

The carbon content of liter of diesel oil is higher than that of gasoline, although $\mathrm{CO}_{2}$ emissions are lower due to smaller fuel consumption per driven kilometer [17]. As one can see, in 2012 excise tax on diesel oil and biodiesel was significantly increased in order to maintain tax rates above the minimum levels of taxation set out in the Energy Directive. In the notes to the draft law, it was pointed out that diesel oil prices in Poland were much lower than in some neighboring countries.

The level of taxation on liquefied petroleum gas in Poland (rate of PLN 670 per tonne) is comparable to average European standards. In 10 European Union countries LPG is taxed at a higher rate [8]. Only in Belgium liquefied petroleum gas is fully exempted from the tax. It is allowed by the article 15 of the Energy Directive to grant total or partial exemptions or reductions in the level of taxation to LPG and natural gas used as propellants.

For some environmental reasons liquefied petroleum gas can be taxed at a lower rate than other fuels as LPG-powered vehicles have lower nitrogen oxides emissions than comparable diesel-engine cars. However, in terms of $\mathrm{CO}_{2}$ emissions there is no significant difference between both [27].

As of 1 November 2013, compressed natural gas is subject to excise duty. Natural gas for vehicle use is important for environmental concerns as this fuel has the lowest carbon dioxide emissions per unit of energy among the carbon-based fuels and low particulate and sulphur dioxide emissions [15, 16]. The tax discourages public transport companies from buying CNG-powered buses and reduces the competitiveness of this fuel relative to diesel oil. In some EU countries (Belgium, Estonia, Greece, Luxemburg and Malta) CNG is fully exempted from the tax pursuant to the article 15 of the Energy Directive [8]. Such an exemption is also planned by the Polish Ministry of Finance.

As of 2011 excise and fuel levies on biofuels and fuels containing bio-components used as substitutes for gasoline and diesel are taxed by the same amount as conventional road-transport fuels. For hydrogen and bio-hydrogen zero excise tax rates are applied. Zero rates were intended to improve the competitiveness of alternative fuels relative to petroleum-based fuels and to address environmental concerns. However, the tax exemption for hydrogen and bio-hydrogen has no practical significance as there are only a few alternative fuel-powered cars currently in use and there are no hydrogen refuelling stations [23].

As illustrated in Figure 1, there appears to be some relationship between liquid fuel prices and liquid fuel use. From 2012 to 2016 average diesel and gasoline prices were decreased by a quarter. As of 2013 diesel consumption increased by $25 \%$ and gasoline use - by $13 \%$. Revenues generated from excise duty paid from the use of liquid motor 
fuels increased throughout the analysed period. In 2016 tax revenues and fuel consumption could be affected by important amendments in Excise Duty Law and Value Added Tax Law, which came into force in September of 2016. Legislative changes (known as a "fuel package") aimed at fighting tax fraud and preventing illegal fuel sale [25].

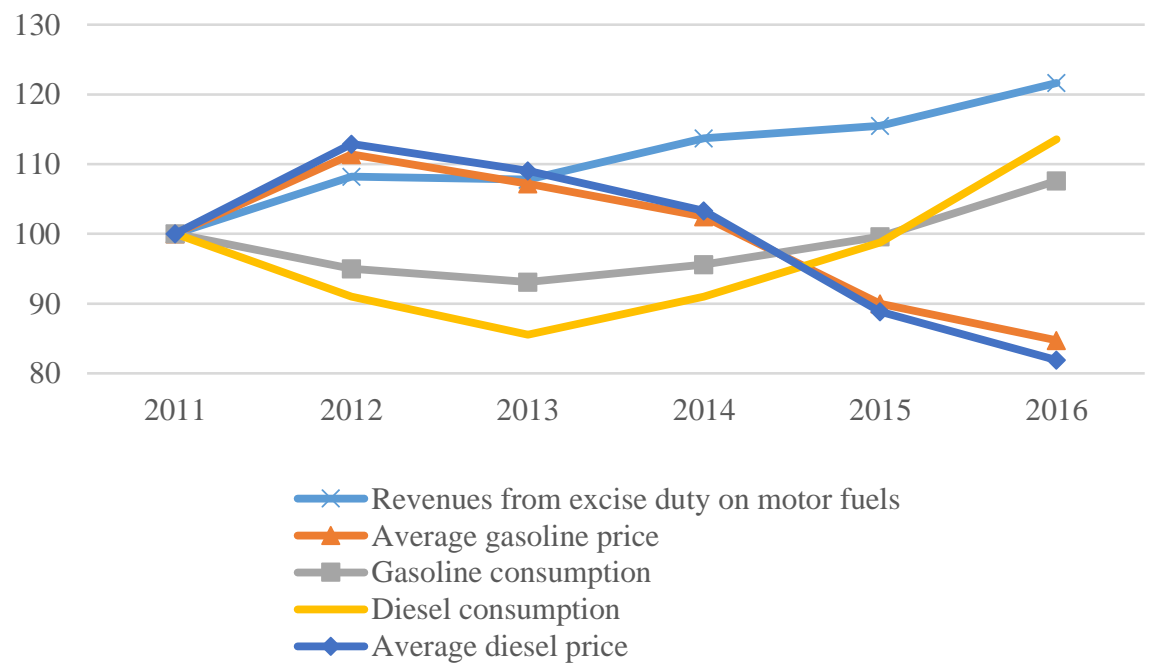

Fig. 1. Indices of average liquid fuel prices, liquid fuel consumption and liquid fuel tax revenues $(2011=100)$. [19]

Research on the price elasticity of demand for gasoline in Poland shows that in 20032012 demand was weakly responsive to price changes. This elasticity was estimated to be slightly negative. Hence, the incentive effects of the excise duty on consumer demand were limited. The tax provided stronger incentives in 1999-2002 when demand was more responsive to price changes [1].

The excise duty and fuel tax rates for the different fuels in Poland are not proportional to their energy content (Table 2). The taxation scheme favours diesel oil over gasoline and LPG and CNG over conventional fuels. The latter can be due to the fact that gaseous fuels are considered cleaner and more environmental friendly compared to gasoline and diesel. Such tax differentiations also apply to fuel taxes in many other European Union countries. Minimum levels of taxation set out in Directive 2003/96/EC favour diesel over gasoline but tax rates on gaseous fuels in terms of energy and carbon content are the same.

In some of the European countries fuel taxation consists of excise duty and carbon $\operatorname{tax}\left(\right.$ or $\mathrm{CO}_{2} \operatorname{tax}$ ) levied on carbon content of a fuel or on the amount of carbon dioxide that a fuel emits when burned. Carbon taxes can be equalized across all types of fossil fuels used for transport and heating. This is not the case for traditional excise duties, which are often differentiated across fuels and sectors of the economy (for example, 
Directive 2003/96/EC permits member states to apply reduced tax rates on the consumption of energy products in energy-intensive business) [34].

Table 2. Tax rates in terms of energy and carbon content (2017). [5, 8]

\begin{tabular}{lccrr}
\hline & Gasoline & Diesel & LPG & CNG \\
\hline \multicolumn{4}{c}{ Tax rates in terms of energy content, euro per GJ } \\
Poland & 11.1 & 9.5 & 4.2 & 3.3 \\
EU-28 maximum level & 24.6 & 18.6 & 9.9 & 11.6 \\
Directive 2003/96/minimum levels & 10.3 & 9.2 & 2.7 & 2.6 \\
\multicolumn{2}{c}{ Implicit carbon taxes, euro per tonne of $\mathrm{CO}_{2}$} \\
Poland & 171.3 & 130.7 & 66.6 & 55.3 \\
EU-28 maximum level & 377.7 & 255.3 & 156.6 & 192.6 \\
Directive 2003/96/minimum levels & 158.1 & 126.9 & 43.1 & 43.3 \\
\hline
\end{tabular}

Among the first countries worldwide that implemented carbon taxes were Finland and Sweden. In Finland, the tax is incorporated into fuel taxes, which consist of two other levies: an excise duty and a strategic stockpile fee imposed on imported fuels. In 2017 the share of carbon tax rate in the total tax rate level is $25 \%$ for gasoline and $38 \%$ for diesel oil (Table 3). Tax rates on bioethanol and biodiesel are reduced. In Sweden carbon tax rate on gasoline and diesel accounts for about $40 \%$ and 53-57\% of the total tax rate respectively. In 2017 the rate of carbon tax in Sweden is about 120 euro per tonne. Excise tax rates are differentiated according to the environmental class of the fuel. Lower tax rates apply to fuels, which are less environmental harmful [31].

Table 3. Taxes on transportation fuels in Finland and Sweden (2017). [22, 30]

\begin{tabular}{lrrrr}
\hline & \multicolumn{1}{c}{ Basic tax } & Carbon tax & Other fees & Total \\
\hline \multirow{2}{*}{ Finland } & \multicolumn{2}{c}{ Gasoline (euro per 1000 litre) } \\
Sweden & 521.9 & 173.8 & 6.8 & 702.5 \\
& $404.5-407.6$ & 273.1 & - & $677.6-680.7$ \\
Finland & \multicolumn{2}{c}{ Diesel oil (euro per 1000 litre) } & & \\
Sweden & 327.7 & 199.0 & 3.5 & 530.2 \\
& $259.6-305.4$ & 337.7 & - & $597.3-642.1$ \\
Finland & \multicolumn{2}{c}{ LPG (euro per 1000 kg) } \\
Sweden & 90.1 & 175.3 & 1.1 & 266.5 \\
\hline
\end{tabular}

In Poland, there is no explicit carbon tax levied on motor fuels however one can assume that existing energy taxation imposes prices on $\mathrm{CO}_{2}$ emissions and introduces 
so called implicit carbon price (implicit carbon tax) [21]. Calculations of implicit carbon taxes are given in Table 2. The calculations are based on taxes that fall under the scope of the of 2003/96/EC Directive. As one can see, tax rates in terms of carbon content are not equalized.

It should be noted that fuels burned in vehicle engines are subject in Poland to emission charge, which is earmarked for environmental and water protection funds. The charge is paid by legal persons (households are excluded from the charge). The charge is levied on fuels used in passenger cars, trucks, buses and other vehicles. The rates of the charge are levied according to weight of the fuel and are calculated and are based on emissions of greenhouse gases such as carbon dioxide, methane and nitrous oxide and on other air pollutants (eg. sulphur dioxide, lead, carbon monoxide, nitrogen oxides, aliphatic hydrocarbons). The rates of the charge are differentiated according to fuel, engine and vehicle type, date of first registration or weight of the vehicle and are very modest. For example, in 2017 the rate of the emission charge was 1.36-63.01 euro per tonne of gasoline (about 1.81-84.01 euro per $1000 \mathrm{l}$ ). The rate on diesel oil is 0.88-12.10 euro per tonne (about 1.17-16.13 euro per 10001 ) [18].

\section{Conclusion}

Fuel taxes in Poland have not been designed to take account of climate policy objectives. However, there are some tax rules that could contribute to $\mathrm{CO}_{2}$ emissions reduction. It includes lower tax rates for gaseous fuels and the use of fuel charge revenues.

Excise duty in Poland could be redesigned to better reflect climate policy objectives and to speed up the transition from fossil fuels to alternative and nonpolluting energy sources in road transport. Changes can consist of annual adjustment of tax rates (as there have been rather minor changes in the excise tax rates since 2009) and introduction of significant $\mathrm{CO}_{2}$ component within the fuel taxation. The latter could replace the emission charge levied on fuels.

It should be kept in mind that the design of the motor fuels tax base, tax rates and exemptions are to a certain extent influenced by the EU law. Environmentally driven changes in the excise duties can be a result of tax harmonisation across the member states.

\section{References}

1. Adamczyk, A., Witkowski, P., Putek-Szeląg, E.: Funkcja fiskalna i funkcja bodźcowa opodatkowania podatkiem akcyzowym paliw silnikowych w Polsce. Zeszyty Naukowe Uniwersytetu Szczecińskiego. Finanse, Rynki Finansowe, Ubezpieczenia 68 (2014).

2. Brons, M., Nijkamp, P., Pels, E., Rietveld, P.: A meta-analysis of the price elasticity of gasoline demand. A SUR approach. Energy Economics, 30 (2008), DOI: 10.1016/j.eneco.2007.08.004.

3. Cela, E., Kaneko, S.: Effectiveness of the Danish Packaging Tax. In: Ashiabor, H., Kreiser, L., Sirisom, J., Milne, J. (eds.): Environmental Taxation and Climate Change: 
Achieving Environmental Sustainable through Fiscal Policy. Edward Elgar, Cheltenham (2011), DOI: $10.4337 / 9780857937872.00030$.

4. Cnossen, S.: Economics and Politics of Excise Taxation. In: Cnossen, S. (ed.): Theory and Practice of Excise Taxation: Smoking, Drinking, Gambling, and Drinking. Oxford University Press, New York (2005), DOI: 10.1093/0199278598.003.0001.

5. Commission of the European Communities: Commission Staff Working Document. Accompanying the Green Paper on Market-Based Instruments for Environment and Energy Related Policy Purposes. COM 140/2007.

6. Council of the European Union: Council Directive 2003/96/EC of 27 October 2003 restructuring the Community framework for the taxation of energy products and electricity. Official Journal of the European Union L 283/2003.

7. Council of the European Union: Council Directive 2008/118/EC of 16 December 2008 concerning the general arrangements for excise duty and repealing Directive 92/12/EEC. Official Journal of the European Union L 9/2009.

8. European Commission: Excise Duty Tables. Part II Energy Products and Electricity. European Commission, Brussels (2017).

9. European Environment Agency: Atmospheric Greenhouse Gas Concentrations, https://www.eea.europa.eu/data-and-maps/indicators/atmospheric-greenhouse-gasconcentrations-5/assessment, last accessed 2017/08/24.

10. Eurostat: Environmental Taxes. A Statistical Guide. Eurostat, Luxembourg (2013).

11. Eurostat: Taxation Trends in the European Union. Data for the EU Member States, Iceland And Norway. Eurostat, Luxembourg 2016.

12. Fujiwara, N., Ferrer, J., Egenhofer, C: The Political Economy of Environmental Taxation in European Countries. CEPS Working Documents 245 (2006).

13. Ibarrarán, M., Boyd, R.: Hacia el Futuro: Energy, Economics and the Environment in 21st Century Mexico. Springer, Dordrecht (2006).

14. Intergovernmental Panel on Climate Change: Climate Change 2014. Mitigation of Climate Change. Cambridge University Press, New York (2014), DOI: 10.1017/CBO9781107415416.

15. Jariwala, A., Jariwala, S.: An Overview of Cleaner Electricity Generation. In: Figueiredo, J., Guillén, M. (eds.): Green Power: Perspectives on Sustainable Electricity Generation. CRC Press, Boca Raton (2014).

16. Kojima, M.: Breathing Clean: Considering the Switch to Natural Gas Buses. The World Bank, Washington (2001), DOI: 10.1596/0-8213-5040-4.

17. Mansvelt, J. (ed.): Green Consumerism: An A-to-Z Guide. Sage Publications, Thousand Oaks (2011), DOI: 10.4135/9781412973809.

18. Minister Środowiska: Obwieszczenie Ministra Środowiska z dnia 29 czerwca 2016 r. w sprawie wysokości stawek opłat za korzystanie ze środowiska na rok 2017. Monitor Polski $718 / 2016$.

19. Ministerstwo Finansów: Sprawozdania z wykonania budżetu państwa, http://www.mf.gov.pl/ministerstwo-finansow/dzialalnosc/finanse-publiczne/budzetpanstwa/wykonanie-budzetu-panstwa/sprawozdanie-z-wykonania-budzetu-panstwaroczne, last accessed 2017/08/21.

20. OECD: Environmentally Related Taxes in OECD Countries Issues and Strategies. OECD, Paris (2001).

21. OECD: OECD Environmental Performance Reviews. South Africa, OECD, Paris (2013).

22. Öljy- ja biopolttoaineala ry: Excise taxes on principal petroleum products, http://www.oil.fi/en/statistics-1-prices-and-taxes/19-excise-taxes-principal-petroleumproducts, last accessed 2017/09/26. 
23. Parulski, S.: Akcyza: komentarz. Wolters Kluwer, Warszawa (2016).

24. Sejm Rzeczypospolitej Polskiej: Projekt ustawy o podatku akcyzowym. Druk nr 1083, Warszawa (2008).

25. Sejm Rzeczypospolitej Polskiej: Projekt ustawy o zmianie ustawy o podatku od towarów i usług oraz o zmianie niektórych innych ustaw. Druk nr 554, Warszawa (2016).

26. Sejm Rzeczypospolitej Polskiej: Rządowy projekt ustawy o zmianie ustawy o autostradach płatnych oraz o Krajowym Funduszu Drogowym, ustawy o Funduszu Kolejowym oraz ustawy o podatku akcyzowym, Druk nr 2494, Warszawa (2014).

27. Shah, Y.: Chemical Energy from Natural and Synthetic Gas. CRC Press, Boca Raton (2017), DOI: 10.1201/9781315302355.

28. Shogren, J.: What Insight Can Economics Offer? In: Owen, A., Hanley, N.: The Economics of Climate Change. Routledge, New York (2004).

29. Sterner, T., Coria, J (eds.): Policy Instruments for Environmental and Natural Resource Management. RFF Press, New York (2012).

30. Svenska Petroleum och Biodrivmedel Institutet: Skatter årsvis, http://spbi.se/statistik/skatter-2/skatter/?df0 $=2015 \& \mathrm{dt} 0=2015 \&$ unit $0=1 \&$ ts $0=0, \quad$ last accessed 2017/09/26.

31. Swedish Tax Agency: Taxes in Sweden. Tax Statistical Yearbook of Sweden 2015, Swedish Tax Agency (2016).

32. Thampapillai, D., Wu, X: Environmental Taxes, Cumulative Pollution Loads, and Fiscal Balance, In: Lye, L., Milne, J., Ashiabor, H., Kreiser, L., Deketelaere, K (eds). Critical Issues in Environmental Taxation. Oxford University Press, Oxford (2009).

33. Tol, R.: Targets for Global Climate Policy: An Overview. Journal of Economic Dynamics and Control 37 (2013), DOI: 10.1016/j.jedc.2013.01.001.

34. Transport Research Centre: Oil Dependence: Is Transport Running out of Affordable Fuel? (2008).

35. Ustawa z dnia 23 października 2014 r. o zmianie ustawy o autostradach płatnych oraz o Krajowym Funduszu Drogowym, ustawy o Funduszu Kolejowym oraz ustawy o podatku akcyzowym. Dziennik Ustaw 1559/2014.

36. Ustawa z dnia 6 grudnia 2008 r. o podatku akcyzowym. Dziennik Ustaw 3/11/2009.

37. Van Wee, B.: Pricing Instruments for Transport Policy. In: Dietz, F.J., Vollebergh, H., de Vries, J. (eds). Environment, Incentives and the Common Market. Kluwer Academic Publishers, Dordrecht (1995), DOI: 10.1007/978-94-011-0113-4_6. 